\title{
Occurrence of breast cancer subtypes in adolescent and young adult women
}

Theresa HM Keegan ${ }^{1,2^{*}}$, Mindy C DeRouen ${ }^{1}$, David J Press ${ }^{1}$, Allison W Kurian ${ }^{2,3}$ and Christina A Clarke ${ }^{1,2}$

\begin{abstract}
Introduction: Breast cancers are increasingly recognized as heterogeneous based on expression of receptors for estrogen (ER), progesterone (PR), and human epidermal growth factor receptor 2 (HER2). Triple-negative tumors (ER/PR'/HER2') have been reported to be more common among younger women, but occurrence of the spectrum of breast cancer subtypes in adolescent and young adult (AYA) women aged between 15 and 39 years is otherwise poorly understood.
\end{abstract}

Methods: Data regarding all 5,605 AYA breast cancers diagnosed in California during the period 2005 to 2009, including ER and PR status (referred to jointly as hormone receptor (HR) status) and HER2 status, was obtained from the population-based California Cancer Registry. Incidence rates were calculated by subtype (triple-negative; $\mathrm{HR}^{+} / \mathrm{HER2}^{-} ; \mathrm{HR}^{+} / \mathrm{HER}^{+} ; \mathrm{HR}^{-} / \mathrm{HER}^{+}$), and logistic regression was used to evaluate differences in subtype characteristics by age group.

Results: AYAs had higher proportions of $\mathrm{HR}^{+} / \mathrm{HER}^{+}$, triple-negative and $\mathrm{HR}^{-} / \mathrm{HER} 2^{+}$breast cancer subtypes and higher proportions of patients of non-White race/ethnicity than did older women. AYAs also were more likely to be diagnosed with stage III/IV disease and high-grade tumors than were older women. Rates of $\mathrm{HR}^{+} / \mathrm{HER2}^{-}$and triple-negative subtypes in AYAs varied substantially by race/ethnicity.

Conclusions: The distribution of breast cancer subtypes among AYAs varies from that observed in older women, and varies further by race/ethnicity. Observed subtype distributions may explain the poorer breast cancer survival previously observed among AYAs.

\section{Introduction}

Breast cancer is the most frequently diagnosed cancer among adolescent and young adult (AYA) women 15 to 39 years of age [1]. Currently, AYA breast cancer accounts for approximately $14 \%$ of all AYA cancer diagnoses and $7 \%$ of all breast cancer diagnoses [1,2]. Evidence suggests that AYA breast cancer may be etiologically as well as clinically distinct from breast cancer in older women [2]. When breast cancer occurs in AYAs, it differs from that occurring in older women in several ways: a worse prognosis and more-aggressive phenotype, higher proportions of high-grade and later stage tumors, lower estrogen receptor (ER) positivity, and overexpression of human epidermal growth factor receptor 2 (HER2) [1,3,4]. Understanding differences between AYA cancers and those

\footnotetext{
* Correspondence: theresa.keegan@cpic.org

'Cancer Prevention Institute of California, 2201 Walnut Ave, Suite 300,

Fremont, CA 94538, USA Full list of author information is available at the end of the article
}

occurring in older populations has been set forth by the National Cancer Institute and LIVESTRONG Young Adult Alliance as important in light of stalled progress in improving outcomes among AYAs with cancer [5].

We recently reported in a large, population-based series from California that the hormone receptor negative, HER2 positive $\left(\mathrm{HR}^{-} / \mathrm{HER} 2^{+}\right)$and triple-negative (ER negative/progesterone receptor (PR) negative/HER2 negative) tumors were more common in younger women $[4,6]$. Other California-based analyses have found a higher incidence rate of triple-negative breast cancer in young (younger than 44 years) Blacks compared with Whites or Hispanics (2004 to 2006) [7] and that young age was associated with triplenegative breast cancer in 1999 to 2003 [8] and 1999 to 2004 [9] data. The Carolina Breast Cancer Study also found triple-negative breast cancer to be more common in premenopausal than postmenopausal women [10]. However, besides triple-negative breast cancer [7], no previous studies have reported incidence rates by molecular breast
C Biomed Central 
cancer subtypes in AYAs. Therefore, the better to understand the occurrence of AYA breast cancer subtypes, we took advantage of HER2 data recently available for breast cancers occurring in the large and diverse California population from 2005 to 2009. In addition, we compared the subtype distribution and demographic and tumor characteristics in AYAs with those in older premenopausal (40 to 49 years) and postmenopausal (50+ years) women.

\section{Methods}

\section{Cancer cases}

We obtained from the California Cancer Registry (CCR) information about all female California residents diagnosed with an invasive breast cancer (International Classification of Disease for Oncology, $3^{\text {rd }}$ Edition, (ICD-O-3) site codes C50.0-50.9) during the period January 1, 2005, through December 31, 2009. Individual informed consent was not obtained, as the analysis was based on state-mandated cancer registry data. For each breast cancer case, we obtained information routinely abstracted from the medical record on age at diagnosis, race/ethnicity (Hispanic, non-Hispanic White, non-Hispanic Black, and non-Hispanic Asian/Pacific Islander, hereafter referred to as "White", "Black", "Hispanic", and "Asian"), AJCC stage at diagnosis (I, II, III, IV, or unstaged/not applicable (NA)), tumor size $(\leq 2 \mathrm{~cm},>2$ $\mathrm{cm}$, microinvasion, diffuse, or unknown), grade (low, high, or unknown), ER, PR, and HER2 tumor-expression status, sequence number (first primary or non-first primary), and prior cancer (no, yes, or unknown). The CCR has collected information on ER and PR since 1990 and on HER2 since 1999 [8]. Before the year 2005, 41\% of cases lacked HER2 data, but data completeness has increased to at least $83 \%$ since that time. Because of the initial reduced reliability of HER2-receptor status [11] and data completeness, we limited our analyses to between 2005 and 2009. ER and PR were evaluated with dextran-coated charcoal assays or immunohistochemistry (IHC); HER2 was tested with IHC or fluorescence in situ hybridization. Each marker was reported as positive, negative, borderline, not tested, not recorded, or unknown, based on the test performed by the laboratory at the reporting facility [12].

Of the 141,002 female breast cancer cases 15 years or older diagnosed between 2005 and 2009 in California, we excluded cases with in situ breast cancer $(n=27,276)$, inflammatory carcinoma $(n=697)$, Paget disease $(n=26)$, mammographic or xerographic diagnosis only $(n=383)$, and death certificate only $(n=363)$. The resulting study population $(N=112,256)$ included 5,605 women aged 15 to 39 years, 19,776 women aged 40 to 49 years, and 86,875 women older than 50 years at diagnosis.

\section{Categorization of breast cancer subtypes}

Breast cancer subtypes were categorized according to tumor expression of ER, PR, and HER2. $\mathrm{HR}^{+} / \mathrm{HER}^{-}$was defined as ER or PR positive and HER2 negative; HR ${ }^{+} / \mathrm{HER}^{+}$as ER or PR positive and HER2 positive; $\mathrm{HR}^{-} /$ HER $^{+}$as ER and PR negative and HER2 positive; and triple-negative as ER, PR, and HER2 negative $[11,13,14]$.

\section{Population denominator data}

We obtained population counts by sex, race/ethnicity, and 5-year age group for the state of California from the 2000 Census Summary File 3 (SF-3) [15]. Data from the 20\% Integrated Public-Use Microdata Sample of the Census also were used to estimate age-specific population counts for Hispanics [16] by smoothing with a spline-based function.

\section{Statistical analysis}

SEER*Stat software [17] was used to compute age-adjusted incidence rates (standardized to the 2000 US standard million population) and 95\% confidence intervals (CIs) for invasive breast cancer. We calculated incidence-rate ratios (IRRs) comparing rates by race/ethnicity, with Whites as the reference. To evaluate differences in the clinical characteristics of breast cancer subtypes by age group (15 to 39 years versus 40 to 49 years; 15 to 39 years versus older than 50 years), and we used logistic regression to calculate odds ratios (OR) and associated 95\% confidence intervals (CIs). Models included race/ethnicity, year of diagnosis, stage at diagnosis, grade, and first primary cancer, and were analyzed by using SAS version 9.2 (Cary, NC, USA). This project was approved by the institutional review board of the Cancer Prevention Institute of California.

\section{Results}

The overall, age-adjusted incidence rate for breast cancer among all AYAs was 18.9 per 100,000 women (95\% CI, 18.4 to 19.4). Incidence of breast cancer for all subtypes increased rapidly between 15 and 39 years of age (Figure 1). Table 1 shows characteristics of AYA breast tumors diagnosed. $62.8 \%$ of AYAs were diagnosed between 35 to 39 years of age (Table 1 ). $\mathrm{HR}^{+} / \mathrm{HER} 2^{-}$ was the most commonly diagnosed AYA subtype (41.1\%), followed by triple-negative (19.1\%), $\mathrm{HR}^{+} / \mathrm{HER} 2^{+}$ (15.0\%) and $\mathrm{HR}^{-} / \mathrm{HER}^{+}$(8.7\%). Most AYA breast cancer patients were of White $(42.7 \%)$ or Hispanic $(32.1 \%)$ race/ethnicity. The highest proportion of stage III/IV disease occurred for the $\mathrm{HR}^{-} / \mathrm{HER} 2^{+}$subtype. A higher proportion of AYAs with triple-negative and $\mathrm{HR}^{-} / \mathrm{HER} 2^{+}$ subtypes presented with high-grade disease than did those diagnosed with the $\mathrm{HR}^{+} / \mathrm{HER} 2^{-}$subtype. Nearly $7 \%$ of AYA breast cancer patients had a prior cancer (any type) before this breast cancer.

Substantial racial/ethnic differences were found in AYA breast cancer. Compared with Whites, Blacks were $24 \%$ less likely to have the $\mathrm{HR}^{+} / \mathrm{HER} 2^{-}$subtype and $61 \%$ more likely to have the triple-negative subtype. Unlike 


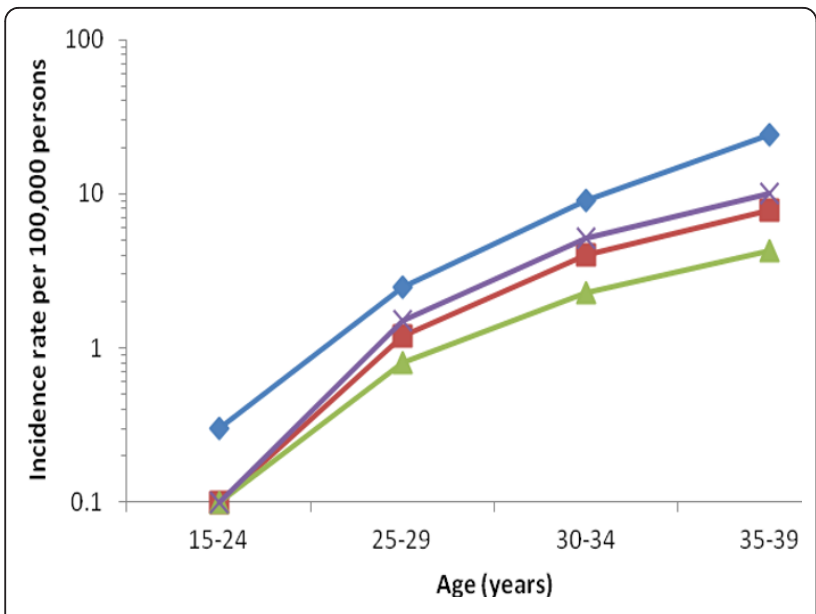

Figure 1 Age-specific incidence rates of breast cancer by subtypes among California women aged 15 to 39 years, 20052009. Hormone receptor (HR)-positive and human epidermal growth factor receptor 2 (HER2)-negative (diamond), $\mathrm{HR}^{+} / \mathrm{HER}^{+}$ (square), $\mathrm{HR}^{-} / \mathrm{HER}^{+}$(triangle), and triple-negative $(\mathrm{X})$.

in the other racial/ethnic groups, in which the incidence of $\mathrm{HR}^{+} / \mathrm{HER}^{-}$is higher than triple-negative breast cancer, Blacks had a similar incidence of $\mathrm{HR}^{+} / \mathrm{HER} 2^{-}$and triple-negative subtypes. In addition, Hispanics were $35 \%$ less likely to be diagnosed with the $\mathrm{HR}^{+} / \mathrm{HER}^{-}$ subtype, and Asians were $36 \%$ less likely to be diagnosed with the triple-negative subtype than were Whites (Table 2).

\section{Comparison of subtypes between age groups}

$\mathrm{HR}^{+} / \mathrm{HER} 2^{-}$was the most common subtype among all age groups, and $\mathrm{HR}^{-} / \mathrm{HER}^{+}{ }^{+}$was the least; however, the relative contribution of each subtype varied within age categories (Figure 2). $\mathrm{HR}^{+} / \mathrm{HER} 2^{-}$comprised an increasing proportion of all breast cancer diagnoses across the life span. By contrast, the relative contribution of $\mathrm{HR}^{+} / \mathrm{HER} 2^{+}$, $\mathrm{HR}^{-} / \mathrm{HER}^{+}$, and triple-negative decreased in successive age groups.

\section{Comparison of patient and clinical characteristics between age groups}

Table 3 presents findings from logistic regression models comparing AYAs with women 40 to 49 years old and women older than 50 years separately to understand how characteristics differed among age groups. Compared with women older than 50 years and relative to Whites, Hispanics, Blacks, and Asians, AYAs were significantly more likely to be diagnosed with breast cancer and all breast cancer subtypes. Compared with women 40 to 49 years old, Hispanics (versus Whites) were more likely to be diagnosed with all subtypes, and Asians (versus Whites) were more likely to be diagnosed with $\mathrm{HR}^{+} / \mathrm{HER}^{-}$and $\mathrm{HR}^{+} / \mathrm{HER}^{+}$ subtypes. Black AYAs (versus Whites) were not significantly more likely than women 40 to 49 years old to be diagnosed with any subtype. AYAs also were significantly more likely to be diagnosed with stage III/IV disease and high-grade disease, except for $\mathrm{HR}^{-} / \mathrm{HER} 2^{+}$breast cancer, than were older women. Compared with older women, AYAs were less likely to have had a prior cancer.

\section{Discussion}

Our population-based study is the first to detail subtypespecific breast cancer occurrence among AYAs, aged 15 to 39 years. Similar to older women, AYAs were most likely to be diagnosed with the $\mathrm{HR}^{+} / \mathrm{HER} 2^{-}$subtype of breast cancer, followed by the triple-negative, $\mathrm{HR}^{+} / \mathrm{HER} 2^{+}$and $\mathrm{HR}^{-} / \mathrm{HER} 2^{+}$subtypes. However, compared with older women, AYAs had higher proportions of $\mathrm{HR}^{+} / \mathrm{HER}^{+}$, triple-negative, and $\mathrm{HR}^{-} / \mathrm{HER} 2^{+}$breast cancer subtypes and higher proportions of patients of non-White race/ethnicity. We also found that subtype distributions differed by race/ethnicity in AYAs, with Blacks and Hispanics less likely to be diagnosed with the $\mathrm{HR}^{+} / \mathrm{HER} 2^{-}$subtype, and Asians less likely and Blacks more likely to be diagnosed with the triple-negative subtype, as compared with Whites. We also found that AYAs were more likely to be diagnosed with stage III/IV disease and high-grade tumors than were older women.

Although previous studies in the CCR have found higher proportions of triple-negative $[4,6,8]$ and $\mathrm{HR}^{-} / \mathrm{HER}^{+}[4,6]$ subtypes in younger women, ours is the first study to report a higher incidence of the $\mathrm{HR}^{+} / \mathrm{HER} 2^{+}$subtype in AYAs compared with older age groups. This distinction is important because $\mathrm{HR}^{+} / \mathrm{HER} 2^{+}$, like the triple-negative and $\mathrm{HR}^{-} / \mathrm{HER} 2^{+}$subtypes, may be associated with worse survival than the $\mathrm{HR}^{+} / \mathrm{HER} 2^{-}$subtype $[10,18]$. The lower proportion of $\mathrm{HR}^{+} / \mathrm{HER} 2^{-}$breast cancer in AYAs compared with older women in our study may contribute to the poor prognosis reported for AYA breast cancer patients as a whole [3].

Poor prognoses among AYAs are particularly relevant to Black, Hispanic, and Asian women, who comprised a larger proportion of young compared with older breast cancer patients. Our results are consistent with previous reports of a higher incidence of breast cancer, especially triple-negative breast cancer $[7,8]$, in young Blacks and relatively lower rates with increasing age for Hispanic and Asian women compared with Whites $[19,20]$. Black women have a high burden of triple-negative breast cancer, which is associated with poorer outcomes after breastconserving therapy compared with other subtypes [21]. In contrast, Asian 15 to 39 year-olds had a much lower incidence of triple-negative breast cancer, consistent with our previous analyses $[4,6]$. We did not find an excess of breast cancer among Asians, in contrast to another California study using different methods of rate calculation [22]. Black and Hispanic women younger than 35 years have 
Table 1 Demographic and clinical characteristics of adolescents and young adults with breast cancer by subtype, ${ }^{a}$ 2005 to 2009

\begin{tabular}{|c|c|c|c|c|c|c|c|c|c|c|c|}
\hline \multirow[b]{2}{*}{ Characteristics } & \multirow{2}{*}{$\begin{array}{r}\text { Total } \\
(N=5,605) \\
N\end{array}$} & \multicolumn{2}{|c|}{$\begin{array}{l}\text { HR }^{+} / \mathrm{HER}^{-\mathrm{a}} \\
(n=2,306)\end{array}$} & \multicolumn{2}{|c|}{$\begin{array}{r}\mathrm{HR}^{+} / \mathrm{HER}^{+\mathrm{a}} \\
(n=843)\end{array}$} & \multicolumn{2}{|c|}{$\begin{array}{r}\text { HR }^{-} / \mathrm{HER}^{+a} \\
(n=485)\end{array}$} & \multicolumn{2}{|c|}{$\begin{array}{r}\text { Triple-negative }^{a} \\
(n=1,073)\end{array}$} & \multicolumn{2}{|c|}{$\begin{array}{r}\text { Unclassified } \\
(n=898)\end{array}$} \\
\hline & & $n$ & Col\% & $n$ & Col\% & $n$ & Col\% & $n$ & Col\% & $n$ & Col\% \\
\hline \multicolumn{12}{|l|}{ Age group (years) } \\
\hline $15-24$ & 97 & 36 & $(1.6)$ & 11 & (1.3) & 12 & $(2.5)$ & 11 & $(1.0)$ & 27 & (3.0) \\
\hline $25-29$ & 482 & 161 & $(7.0)$ & 81 & (9.6) & 53 & (10.9) & 98 & $(9.1)$ & 89 & $(9.9)$ \\
\hline $30-34$ & 1,507 & 557 & $(24.2)$ & 246 & $(29.2)$ & 144 & $(29.7)$ & 319 & $(29.7)$ & 241 & (26.8) \\
\hline $35-39$ & 3,519 & 1,552 & $(67.3)$ & 505 & $(59.9)$ & 276 & $(56.9)$ & 645 & $(60.1)$ & 541 & $(60.2)$ \\
\hline \multicolumn{12}{|l|}{ Race/ethnicity } \\
\hline White & 2,394 & 1,050 & $(45.5)$ & 347 & $(41.2)$ & 198 & $(40.8)$ & 430 & $(40.1)$ & 369 & $(41.1)$ \\
\hline Black & 421 & 135 & (5.9) & 66 & (7.8) & 39 & (8.0) & 117 & $(10.9)$ & 64 & (7.1) \\
\hline Hispanic & 1,801 & 678 & $(29.4)$ & 271 & $(32.2)$ & 166 & $(34.2)$ & 394 & $(36.7)$ & 292 & (32.5) \\
\hline Asian & 917 & 423 & $(18.3)$ & 152 & (18.0) & 79 & $(16.3)$ & 116 & $(10.8)$ & 147 & (16.4) \\
\hline Unknown/other & 72 & 20 & $(0.9)$ & 7 & $(0.8)$ & b & & 16 & $(1.5)$ & 26 & (2.9) \\
\hline \multicolumn{12}{|l|}{ Year of diagnosis } \\
\hline 2005 & 1,134 & 367 & $(15.9)$ & 157 & $(18.6)$ & 101 & $(20.8)$ & 226 & $(21.1)$ & 283 & $(31.5)$ \\
\hline 2006 & 1,133 & 444 & $(19.3)$ & 192 & $(22.8)$ & 106 & $(21.9)$ & 212 & $(19.8)$ & 179 & (19.9) \\
\hline 2007 & 1,074 & 463 & $(20.1)$ & 145 & $(17.2)$ & 100 & $(20.6)$ & 207 & $(19.3)$ & 159 & $(17.7)$ \\
\hline 2008 & 1,205 & 540 & $(23.4)$ & 168 & $(19.9)$ & 103 & $(21.2)$ & 239 & $(22.3)$ & 155 & $(17.3)$ \\
\hline 2009 & 1,059 & 492 & $(21.3)$ & 181 & $(21.5)$ & 75 & $(15.5)$ & 189 & $(17.6)$ & 122 & (13.6) \\
\hline \multicolumn{12}{|l|}{ AJCC stage at diagnosis } \\
\hline 1 & 1,435 & 722 & (31.3) & 183 & $(21.7)$ & 94 & $(19.4)$ & 212 & $(19.8)$ & 224 & $(24.9)$ \\
\hline$\|$ & 2,425 & 956 & $(41.5)$ & 365 & (43.3) & 199 & $(41.0)$ & 541 & $(50.4)$ & 364 & $(40.5)$ \\
\hline III & 1,102 & 430 & (18.6) & 214 & $(25.4)$ & 126 & $(26.0)$ & 213 & (19.9) & 119 & (13.3) \\
\hline IV & 327 & 127 & $(5.5)$ & 47 & (5.6) & 45 & (9.3) & 63 & (5.9) & 45 & (5.0) \\
\hline Unstaged/NA & 316 & 71 & (3.1) & 34 & $(4.0)$ & 21 & $(4.3)$ & 44 & $(4.1)$ & 146 & (16.3) \\
\hline \multicolumn{12}{|l|}{ Grade } \\
\hline Low & 2,222 & 1,370 & $(59.4)$ & 341 & $(40.5)$ & 104 & $(21.4)$ & 100 & $(9.3)$ & 307 & $(34.2)$ \\
\hline High & 3,022 & 849 & $(36.8)$ & 466 & $(55.3)$ & 356 & $(73.4)$ & 939 & $(87.5)$ & 412 & $(45.9)$ \\
\hline Unknown & 361 & 87 & (3.8) & 36 & $(4.3)$ & 25 & $(5.2)$ & 34 & (3.2) & 179 & (19.9) \\
\hline \multicolumn{12}{|l|}{ Tumor size } \\
\hline$\leq 2 \mathrm{~cm}$ & 2,165 & 1,056 & $(45.8)$ & 326 & (38.9) & 157 & $(32.4)$ & 320 & $(29.8)$ & 306 & (34.0) \\
\hline$>2 \mathrm{~cm}$ & 3,093 & 1,177 & $(51.0)$ & 479 & $(57.1)$ & 284 & $(58.6)$ & 705 & $(65.7)$ & 448 & $(49.8)$ \\
\hline Microinvasion & 56 & 15 & $(0.7)$ & 7 & $(0.8)$ & 8 & (1.7) & b & & 26 & (2.9) \\
\hline Diffuse & 38 & 10 & $(0.4)$ & $\mathrm{b}$ & & 12 & $(2.5)$ & 9 & $(0.8)$ & b & \\
\hline Unknown & 253 & 48 & $(2.1)$ & 27 & $(3.2)$ & 24 & $(5.0)$ & 39 & (3.6) & 115 & $(12.8)$ \\
\hline \multicolumn{12}{|c|}{ Lymph node involvement } \\
\hline No & 2,761 & 1,155 & $(50.1)$ & 358 & $(42.5)$ & 189 & $(39.0)$ & 566 & $(52.8)$ & 493 & $(54.9)$ \\
\hline Yes & 2,707 & 1,123 & $(48.7)$ & 472 & $(56.0)$ & 286 & $(59.0)$ & 491 & $(45.8)$ & 335 & (37.3) \\
\hline Unknown & 137 & 28 & $(1.2)$ & 13 & $(1.5)$ & 10 & $(2.1)$ & 16 & $(1.5)$ & 70 & $(7.8)$ \\
\hline \multicolumn{12}{|l|}{ Prior cancer } \\
\hline First primary & 5,226 & 2,169 & $(94.1)$ & 796 & $(94.4)$ & 459 & $(94.6)$ & 993 & $(92.5)$ & 832 & $(92.7)$ \\
\hline Non-first primary & 379 & 137 & $(5.9)$ & 47 & $(5.6)$ & 26 & $(5.4)$ & 80 & $(7.5)$ & 66 & $(7.3)$ \\
\hline
\end{tabular}

${ }^{a}$ Human epidermal growth factor receptor 2 (HER2), hormone receptor (HR), triple-negative (estrogen-receptor negative, progesterone-receptor negative, HER2-). ${ }^{\mathrm{b}} \mathrm{Statistic}$ not displayed because of five or fewer cases.

been found to have a poorer survival than White women [23], a finding that could be due, in part, to the lower proportion of $\mathrm{HR}^{+} / \mathrm{HER}^{-}$cancer in Black and Hispanic AYAs and a higher proportion of triple-negative breast cancer in Blacks.
Risk factors for breast cancer when treated as a single entity have been reported to differ by age [24], race/ethnicity [25,26], and hormone-receptor status [27-31]. Multiparity [24], prior mantle radiation for Hodgkin lymphoma [32], oral contraceptive use [33], and a low 
Table 2 Age-adjusted breast cancer incidence rates among adolescent and young adults by subtype, ${ }^{a}$ California, 2005 to 2009

\begin{tabular}{|c|c|c|c|c|c|}
\hline Characteristics & $\begin{array}{l}\text { Total } \\
\text { rate }(95 \% \mathrm{Cl})^{\mathrm{b}}\end{array}$ & $\begin{array}{l}\mathrm{HR}^{+} / \mathrm{HER2}^{-} \\
\text {rate }(95 \% \mathrm{Cl})\end{array}$ & $\begin{array}{l}\mathrm{HR}^{+} / \mathrm{HER2}^{+} \\
\text {rate }(95 \% \mathrm{Cl})\end{array}$ & $\begin{array}{l}\text { HR }^{-} / \mathrm{HER2}^{+} \\
\text {rate }(95 \% \mathrm{Cl})\end{array}$ & $\begin{array}{l}\text { Triple-negative } \\
\text { rate }(95 \% \mathrm{Cl})\end{array}$ \\
\hline \multicolumn{6}{|l|}{ Age group (years) } \\
\hline $15-24$ & $0.7(0.6-0.9)$ & $0.3(0.2-0.4)$ & $0.1(0.0-0.2)$ & $0.1(0.0-0.2)$ & $0.1(0.0-0.2)$ \\
\hline $25-29$ & $7.4(6.8-8.1)$ & $2.5(2.1-2.9)$ & $1.2(1.0-1.5)$ & $0.8(0.6-1.1)$ & $1.5(1.2-1.8)$ \\
\hline $30-34$ & $24.4(23.2-25.7)$ & $9.0(8.3-9.8)$ & $4.0(3.5-4.5)$ & $2.3(2.0-2.7)$ & $5.2(4.6-5.8)$ \\
\hline $35-39$ & $54.5(52.7-56.3)$ & $24.0(22.8-25.2)$ & $7.8(7.1-8.5)$ & $4.3(3.8-4.8)$ & $10.0(9.2-10.8)$ \\
\hline \multicolumn{6}{|l|}{ Race/ethnicity } \\
\hline White & $21.0(20.2-21.9)$ & $9.2(8.7-9.8)$ & $3.0(2.7-3.4)$ & $1.7(1.5-2.0)$ & $3.8(3.4-4.1)$ \\
\hline Black & $21.8(19.7-23.9)$ & $7.0(5.9-8.3)$ & $3.4(2.6-4.3)$ & $2.0(1.4-2.8)$ & $6.1(5.0-7.3)$ \\
\hline Hispanic & $15.8(15.1-16.6)$ & $6.0(5.6-6.5)$ & $2.4(2.1-2.7)$ & $1.4(1.2-1.7)$ & $3.4(3.1-3.8)$ \\
\hline Asian & $19.4(18.1-20.7)$ & $9.0(8.2-9.9)$ & $3.2(2.7-3.8)$ & $1.6(1.3-2.1)$ & $2.4(2.0-2.9)$ \\
\hline \multicolumn{6}{|c|}{ Incidence rate ratio } \\
\hline White & Reference & Reference & Reference & Reference & Reference \\
\hline Black & $1.04(0.93-1.16)$ & $0.76(0.63-0.91)$ & $1.11(0.85-1.44)$ & $1.18(0.83-1.66)$ & $1.61(1.31-1.97)$ \\
\hline Hispanic & $0.75(0.70-0.81)$ & $0.65(0.54-0.79)$ & $0.78(0.60-1.02)$ & $0.83(0.58-1.17)$ & $0.91(0.74-1.12)$ \\
\hline Asian & $0.92(0.84-1.01)$ & $0.98(0.87-1.10)$ & $1.05(0.86-1.28)$ & $0.95(0.73-1.25)$ & $0.64(0.52-0.79)$ \\
\hline \multicolumn{6}{|c|}{ AJCC Stage at diagnosis } \\
\hline 1 & $4.9(4.6-5.1)$ & $2.5(2.3-2.6)$ & $0.6(0.5-0.7)$ & $0.3(0.3-0.4)$ & $0.7(0.6-0.8)$ \\
\hline$\|$ & $8.2(7.9-8.5)$ & $3.3(3.0-3.5)$ & $1.2(1.1-1.4)$ & $0.7(0.6-0.8)$ & $1.8(1.7-2.0)$ \\
\hline III & $3.7(3.5-3.9)$ & $1.5(1.3-1.6)$ & $0.7(0.6-0.8)$ & $0.4(0.3-0.5)$ & $0.7(0.6-0.8)$ \\
\hline IV & $1.1(1.0-1.2)$ & $0.4(0.4-0.5)$ & $0.2(0.1-0.2)$ & $0.1(0.1-0.2)$ & $0.2(0.2-0.3)$ \\
\hline \multicolumn{6}{|l|}{ Grade } \\
\hline Low & $7.5(7.2-7.8)$ & $4.7(4.4-4.9)$ & $1.1(1.0-1.3)$ & $0.3(0.3-0.4)$ & $0.3(0.3-0.4)$ \\
\hline High & $10.2(9.8-10.6)$ & $2.9(2.7-3.1)$ & $1.6(1.4-1.7)$ & $1.2(1.1-1.3)$ & $3.2(3.0-3.4)$ \\
\hline \multicolumn{6}{|l|}{ Tumor size } \\
\hline$\leq 2 \mathrm{~cm}$ & $7.3(7.0-7.7)$ & $3.6(3.4-3.8)$ & $1.1(1.0-1.2)$ & $0.5(0.4-0.6)$ & $1.1(1-1.2)$ \\
\hline$>2 \mathrm{~cm}$ & $10.4(10.0-10.8)$ & $4.0(3.8-4.2)$ & $1.6(1.5-1.8)$ & $0.9(0.8-1.1)$ & $2.4(2.2-2.5)$ \\
\hline Microinvasion & $0.2(0.1-0.2)$ & c & c & c & c \\
\hline Diffuse & $0.1(0.1-0.2)$ & c & c & c & c \\
\hline \multicolumn{6}{|c|}{ Lymph node involvement } \\
\hline No & $9.3(9.0-9.7)$ & $3.9(3.7-4.2)$ & $1.2(1.1-1.3)$ & $0.6(0.5-0.7)$ & $1.9(1.8-2.1)$ \\
\hline Positive & $9.1(8.8-9.5)$ & $3.8(3.6-4.0)$ & $1.6(1.4-1.7)$ & $1.0(0.9-1.1)$ & $1.7(1.5-1.8)$ \\
\hline \multicolumn{6}{|l|}{ Prior cancer } \\
\hline First primary & $17.7(17.2-18.2)$ & $7.4(7.1-7.7)$ & $2.7(2.5-2.9)$ & $1.5(1.4-1.7)$ & $3.3(3.1-3.6)$ \\
\hline Non-first primary & $1.9(1.7-2.1)$ & $0.7(0.6-0.8)$ & $0.3(0.2-0.3)$ & $0.2(0.1-0.2)$ & $0.4(0.3-0.5)$ \\
\hline Total & $18.9(18.4-19.4)$ & $7.8(7.5-8.2)$ & $2.8(2.6-3.0)$ & $1.6(1.5-1.8)$ & $3.6(3.4-3.8)$ \\
\hline
\end{tabular}

${ }^{a}$ Human epidermal growth factor receptor 2 (HER2), hormone receptor (HR), triple-negative (estrogen-receptor negative, progesterone-receptor negative, HER2-). ${ }^{b} 95 \%$ confidence interval. 'Statistic not displayed because of fewer than 15 cases.

body mass index [34] are associated with breast cancer in young women and may vary by race/ethnicity $[35,36]$. Although studies have found that White women are more likely to experience risk factors for postmenopausal breast cancer, similar associations based on race/ethnicity are less clear for young women and should be the focus of future research. Given the differences observed in subtype distribution by age, it is probable that subtype-specific risk factors explain the heterogeneity of risk observed for breast cancer as a single entity.
Risk factor heterogeneity also has been reported by tumor ER and PR status [29,37] and, more recently, for HER2 status $[11,29]$. In pooled analyses, reproductive risk factors (age at menarche, parity, and age at first birth) and body mass index were associated with risk of HR positive, but not triple-negative tumors [31]. The only risk factor associated with the development of triple-negative tumors was family history, which was associated positively with all subtypes [31]. The Women's Health Initiative also reported appreciable differences among postmenopausal 


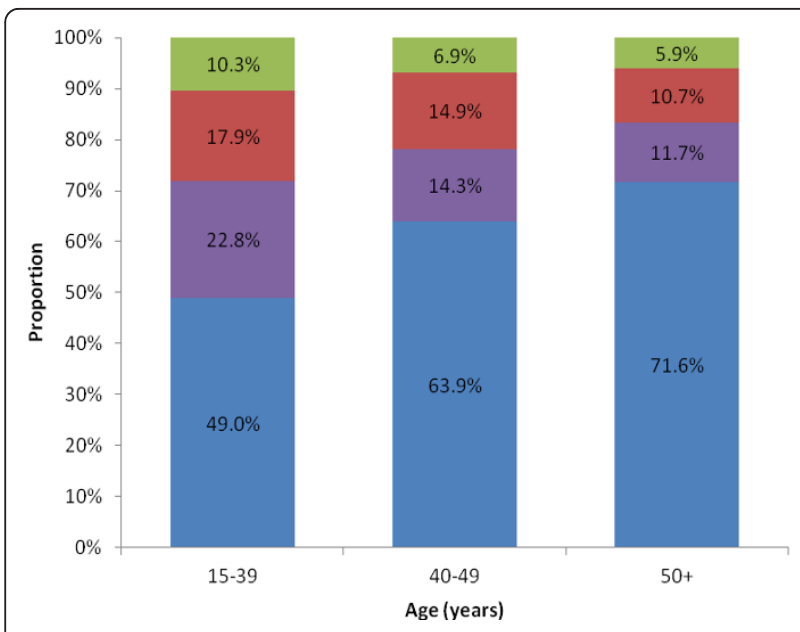

Figure 2 Proportion of breast cancer subtypes among California women by age group, 2005-2009. Hormone receptor (HR)-positive and human epidermal growth factor receptor 2 (HER2) negative (blue), $\mathrm{HR}^{+} / \mathrm{HER}^{+}$(red), $\mathrm{HR}^{-} / \mathrm{HER} 2^{+}$(green), and triplenegative (purple).

women for ER-positive versus triple-negative breast cancers with regard to risk factor associations with reproductive history and oral contraceptive use [28], but not body size or physical activity [27]. Future studies should continue to include information on HER2 status and also address how risk factors are associated with breast cancer subtypes, while considering age and race/ethnicity.

Genetic or other non-environmental contributions may explain the higher incidence of triple-negative breast cancer among Black women than White women [30]. A greater proportion of early breast cancer diagnoses are associated with germline mutations of BRCA1/2 [38] and TP53 [39]. BRCA1 mutations are associated with triplenegative breast cancer [40], which may contribute to the early age distribution of this subtype. Efforts to determine the prevalence of BRCA1/2 mutations in White versus Black populations, however, have been mixed [30,41]. Li Fraumeni syndrome, due to TP53 mutations, also is more prevalent in early-onset $\mathrm{HR}^{-} / \mathrm{HER} 2^{+}$breast cancer [42], but the incidence of this disease is not known to differ by race/ethnicity [39].

Compared with older women, AYAs in our study were more likely to be diagnosed with stage III/IV and higher grade breast cancer and less likely to have been diagnosed with a previous cancer. Our multivariable-adjusted stage and grade results are consistent with results from univariate analyses in smaller studies $[3,43]$. Given the lack of screening mammography advisements for AYAs, whose diagnoses tend to follow identification of a palpable mass [44], it is not surprising that these women would present with later stage, higher grade disease. Despite the expectation that AYAs are more likely to have genetic syndromes that predispose them to cancer $[39,41]$, we found that older women were more likely to have a prior cancer; presumably because older women had more time to acquire cancer-causing mutations.

Our study is the first, to our knowledge, to use population-based registry data for which ER, PR, and HER2 status are sufficiently complete to present breast cancer incidence rates in AYAs for the four major molecular subtypes by race/ethnicity. Another strength of our study is the relatively low percentage (16\%) of women whose breast cancers were unclassified because of missing ER, PR, or HER2 receptor information compared with prior analyses $[7,8]$. To maximize the availability of HER2-receptor status, however, our study was restricted to diagnoses between 2005 and 2009, limiting the number of AYAs included. Although the reliability of ER and PR tests can be controversial [45], evidence suggests that results from a centralized pathology laboratory agree with registry reports for ER and PR status [46]. However, HER2 testing between community-based hospitals and centralized reference laboratories has been found to contain some disagreement [47]. Consensusbased methods to improve laboratory assays will continue to increase the reliability of ER, PR, and HER2 tests $[48,49]$. As with other studies that consider breast cancer subtype according to receptor status, we may be limited in that subtypes determined by ER, PR, and HER2 receptor status serve only as a proxy for full genetic profiling. These ER, PR, and HER2 designations, however, guide clinical treatment [50] and are becoming increasingly useful in epidemiologic research $[4,10,21,29]$. Our study is also subject to the potential misclassification of race/ethnicity, although we have detected excellent overall agreement with self-reported race/ethnicity for Whites and Blacks, and intermediate agreement for Hispanics and Asians [51,52].

\section{Conclusions}

Our study adds to the evidence that AYA women with breast cancer have larger proportions of $\mathrm{HR}^{+} / \mathrm{HER} 2^{+}$, $\mathrm{HR}^{-} / \mathrm{HER} 2^{+}$, and triple-negative subtypes as compared with older women. Compared with White AYAs, Black and Hispanic women had lower incidence rates of HR +/HER2' cancer, whereas Black women had higher rates and Asians had lower rates of triple-negative breast cancer. In addition, AYAs are more likely to be of Black, Hispanic, or Asian than of White race/ethnicity and diagnosed with stage III/IV and high-grade disease compared with older women. The subtype distributions may explain the poorer breast cancer survival previously observed in AYAs. Additional research is needed to understand more fully the racial/ethnic differences in breast cancer subtypes among AYAs. 
Table 3 Odds ratios ${ }^{\mathrm{a}}$ for breast cancer diagnosis (15 to 39 versus 40 to 49 and $50+$ years of age), by subtype ${ }^{\mathrm{b}}$

\begin{tabular}{|c|c|c|c|c|c|c|c|c|c|c|}
\hline \multirow[b]{2}{*}{ Characteristics } & \multicolumn{2}{|c|}{ Total } & \multicolumn{2}{|c|}{$\mathrm{HR}^{+} / \mathrm{HER2}^{-}$} & \multicolumn{2}{|c|}{$\mathrm{HR}^{+} / \mathrm{HER}^{+}$} & \multicolumn{2}{|c|}{ HR $^{-} / \mathrm{HER}^{+}$} & \multicolumn{2}{|c|}{ Triple-negative } \\
\hline & $\begin{array}{l}15-39 / 40-49 \\
\text { OR }(95 \% \mathrm{CI})^{\mathrm{c}}\end{array}$ & $\begin{array}{l}\text { 15-39/50+ } \\
\text { OR (95\% Cl) }\end{array}$ & $\begin{array}{l}15-39 / 40-49 \\
\text { OR }(95 \% \mathrm{Cl})\end{array}$ & $\begin{array}{l}15-39 / 50+ \\
\text { OR }(95 \% \mathrm{Cl})\end{array}$ & $\begin{array}{l}15-39 / 40-49 \\
\text { OR }(95 \% \mathrm{Cl})\end{array}$ & $\begin{array}{l}15-39 / 50+ \\
\text { OR }(95 \% \mathrm{Cl})\end{array}$ & $\begin{array}{l}15-39 / 40-49 \\
\text { OR }(95 \% \mathrm{Cl})\end{array}$ & $\begin{array}{l}15-39 / 50+ \\
\text { OR }(95 \% \mathrm{Cl})\end{array}$ & $\begin{array}{l}15-39 / 40-49 \\
\text { OR }(95 \% \mathrm{Cl})\end{array}$ & $\begin{array}{l}15-39 / 50+ \\
\text { OR }(95 \% \mathrm{Cl})\end{array}$ \\
\hline \multicolumn{11}{|l|}{ Race/ethnicity } \\
\hline White & Reference & Reference & Reference & Reference & Reference & Reference & Reference & Reference & Reference & Reference \\
\hline Hispanic & $\begin{array}{l}1.58 \\
(1.47-1.69)\end{array}$ & $\begin{array}{l}3.25 \\
(3.04-3.45)\end{array}$ & $\begin{array}{l}1.59 \\
(1.43-1.77)\end{array}$ & $\begin{array}{l}3.23 \\
(2.92-3.58)\end{array}$ & $\begin{array}{l}1.51 \\
(1.25-1.82)\end{array}$ & $\begin{array}{l}2.92 \\
(2.46-3.48)\end{array}$ & $\begin{array}{l}1.36 \\
(1.06-1.75)\end{array}$ & $\begin{array}{l}2.63 \\
(2.1-3.29)\end{array}$ & $\begin{array}{l}1.52 \\
(1.29-1.8)\end{array}$ & $\begin{array}{l}3.26 \\
(2.8-3.79)\end{array}$ \\
\hline Asian & $\begin{array}{l}1.32 \\
(1.21-1.44)\end{array}$ & $\begin{array}{l}2.47 \\
(2.28-2.67)\end{array}$ & $\begin{array}{l}1.52 \\
(1.34-1.73)\end{array}$ & $\begin{array}{l}3.00 \\
(2.67-3.38)\end{array}$ & $\begin{array}{l}1.30 \\
(1.04-1.62)\end{array}$ & $\begin{array}{l}2.26 \\
(1.84-2.77)\end{array}$ & $\begin{array}{l}1.00 \\
(0.73-1.36)\end{array}$ & $\begin{array}{l}1.44 \\
(1.09-1.9)\end{array}$ & $\begin{array}{l}1.26 \\
(0.99-1.62)\end{array}$ & $\begin{array}{l}1.96 \\
(1.57-2.45)\end{array}$ \\
\hline Black & $\begin{array}{l}1.13 \\
(1.00-1.27)\end{array}$ & $\begin{array}{l}1.69 \\
(1.52-1.89)\end{array}$ & $\begin{array}{l}1.15 \\
(0.94-1.40)\end{array}$ & $\begin{array}{l}1.66 \\
(1.38-2.00)\end{array}$ & $\begin{array}{l}1.17 \\
(0.86-1.58)\end{array}$ & $\begin{array}{l}1.82 \\
(1.37-2.42)\end{array}$ & $\begin{array}{l}1.37 \\
(0.90-2.09)\end{array}$ & $\begin{array}{l}1.70 \\
(1.18-2.46)\end{array}$ & $\begin{array}{l}0.94 \\
(0.74-1.19)\end{array}$ & $\begin{array}{l}1.38 \\
(1.11-1.71)\end{array}$ \\
\hline \multicolumn{11}{|c|}{ AJCC stage at diagnosis } \\
\hline$|/| \mid$ & Reference & Reference & Reference & Reference & Reference & Reference & Reference & Reference & Reference & Reference \\
\hline III/IV & $\begin{array}{l}1.33 \\
(1.24-1.43)\end{array}$ & $\begin{array}{l}1.58 \\
(1.47-1.68)\end{array}$ & $\begin{array}{l}1.38 \\
(1.24-1.55)\end{array}$ & $\begin{array}{l}1.82 \\
(1.64-2.02)\end{array}$ & $\begin{array}{l}1.51 \\
(1.26-1.80)\end{array}$ & $\begin{array}{l}1.65 \\
(1.40-1.94)\end{array}$ & $\begin{array}{l}1.22 \\
(0.97-1.54)\end{array}$ & $\begin{array}{l}1.44 \\
(1.17-1.76)\end{array}$ & $\begin{array}{l}1.35 \\
(1.13-1.60)\end{array}$ & $\begin{array}{l}1.40 \\
(1.20-1.63)\end{array}$ \\
\hline \multicolumn{11}{|l|}{ Grade } \\
\hline Low & Reference & Reference & Reference & Reference & Reference & Reference & Reference & Reference & Reference & Reference \\
\hline High & $\begin{array}{l}1.82 \\
(1.71-1.94)\end{array}$ & $\begin{array}{l}2.56 \\
(2.41-2.71)\end{array}$ & $\begin{array}{l}1.75 \\
(1.59-1.93)\end{array}$ & $\begin{array}{l}2.37 \\
(2.16-2.60)\end{array}$ & $\begin{array}{l}1.29 \\
(1.10-1.52)\end{array}$ & $\begin{array}{l}1.59 \\
(1.37-1.85)\end{array}$ & $\begin{array}{l}0.85 \\
(0.65-1.11)\end{array}$ & $\begin{array}{l}1.05 \\
(0.83-1.32)\end{array}$ & $\begin{array}{l}1.53 \\
(1.21-1.95)\end{array}$ & $\begin{array}{l}2.87 \\
(2.31-3.55)\end{array}$ \\
\hline \multicolumn{11}{|l|}{ Prior cancer } \\
\hline $1^{\text {st }}$ Primary & Reference & Reference & Reference & Reference & Reference & Reference & Reference & Reference & Reference & Reference \\
\hline $\begin{array}{l}\text { Non- } 1^{\text {st }} \\
\text { primary }\end{array}$ & $\begin{array}{l}0.72 \\
(0.64-0.81)\end{array}$ & $\begin{array}{l}0.32 \\
(0.29-0.36)\end{array}$ & $\begin{array}{l}0.71 \\
(0.59-0.85)\end{array}$ & $\begin{array}{l}0.29 \\
(0.24-0.35)\end{array}$ & $\begin{array}{l}0.84 \\
(0.60-1.17)\end{array}$ & $\begin{array}{l}0.33 \\
(0.24-0.44)\end{array}$ & $\begin{array}{l}0.57 \\
(0.37-0.90)\end{array}$ & $\begin{array}{l}0.32 \\
(0.21-0.48)\end{array}$ & $\begin{array}{l}0.60 \\
(0.46-0.78)\end{array}$ & $\begin{array}{l}0.41 \\
(0.32-0.51)\end{array}$ \\
\hline
\end{tabular}

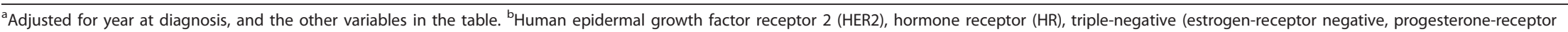
negative, HER2). ' ${ }^{\mathrm{C}}$ Odds ratios (95\% confidence intervals). 


\section{Abbreviations}

AYA: adolescent and young adult; CCR: California Cancer Registry; Cl: confidence interval; ER: estrogen receptor; HER2: human epidermal growth factor receptor 2; HR: hormone receptor; IHC: immunohistochemistry; IRR: incidence rate ratio; OR: odds ratio; PR: progesterone receptor.

\section{Acknowledgements}

The collection of cancer incidence data used in this study was supported by the California Department of Public Health as part of the statewide cancerreporting program mandated by California Health and Safety Code Section 103885; the National Cancer Institute's Surveillance, Epidemiology, and End Results Program under contract HHSN2612010000140C awarded to the Cancer Prevention Institute of California, contract HHSN261201000035C, awarded to the University of Southern California, and contract HHSN261201000034C, awarded to the Public Health Institute; and the Centers for Disease Control and Prevention National Program of Cancer Registries, under agreement 1U58 DP000807-01, awarded to the Public Health Institute. The ideas and opinions expressed herein are those of the authors, and endorsement by the State of California, Department of Health Services, the National Cancer Institute, and the Centers for Disease Control and Prevention or their contractors and subcontractors is not intended nor should it be inferred.

\section{Author details}

'Cancer Prevention Institute of California, 2201 Walnut Ave, Suite 300, Fremont, CA 94538, USA. ²Division of Epidemiology, Department of Health Research and Policy, Stanford University School of Medicine, Stanford, CA 94305, USA. ${ }^{3}$ Department of Medicine, Stanford University School of Medicine, 300 Pasteur Drive, Stanford, CA 94305, USA.

\section{Authors' contributions}

DJP performed the statistical analysis. DJP, AWK, and CAC participated in the interpretation of data, and in the drafting and critical review of the manuscript. THMK and MCD designed the study, interpreted the data, and led the writing and review of the manuscript. All authors read and approved the final manuscript.

\section{Competing interests}

The authors declare that they have no competing interests.

Received: 23 January 2012 Revised: 2 March 2012

Accepted: 27 March 2012 Published: 27 March 2012

\section{References}

1. Bleyer A, Barr R, Hayes-Lattin B, Thomas D, Ellis C, Anderson B: The distinctive biology of cancer in adolescents and young adults. Nat Rev Cancer 2008, 8:288-298.

2. Gabriel CA, Domchek SM: Breast cancer in young women. Breast Cancer Res 2010, 12:212

3. Gnerlich JL, Deshpande AD, Jeffe DB, Sweet A, White N, Margenthaler JA: Elevated breast cancer mortality in women younger than age 40 years compared with older women is attributed to poorer survival in earlystage disease. J Am Coll Surg 2009, 208:341-347.

4. Kurian A, Fish K, Shema S, Clarke C: Lifetime risks of specific breast cancer subtypes among women in four racial/ethnic groups. Breast Cancer Res 2010, 12:R99.

5. Schmidt C: Lack of progress in teen and young adult cancers concerns researchers, prompts study. J Natl Cancer Inst 2006, 98:1760-1763.

6. Telli ML, Chang ET, Kurian AW, Keegan TH, McClure LA, Lichtensztajn D, Ford JM, Gomez SL: Asian ethnicity and breast cancer subtypes: a study from the California Cancer Registry. Breast Cancer Res Treat 2011, 127:471-478

7. Amirikia KC, Mills P, Bush J, Newman LA: Higher population-based incidence rates of triple-negative breast cancer among young AfricanAmerican women: jmplications for breast cancer screening recommendations. Cancer 2011, 117:2747-2753.

8. Bauer KR, Brown M, Cress RD, Parise CA, Caggiano V: Descriptive analysis of estrogen receptor (ER)-negative, progesterone receptor (PR)-negative, and HER2-negative invasive breast cancer, the so-called triple-negative phenotype: a population-based study from the California Cancer Registry. Cancer 2007, 109:1721-1728.
9. Parise CA, Bauer KR, Caggiano V: Variation in breast cancer subtypes with age and race/ethnicity. Crit Rev Oncol Hematol 2010, 76:44-52.

10. Carey LA, Perou CM, Livasy CA, Dressler LG, Cowan D, Conway K, Karaca G, Troester MA, Tse CK, Edmiston S: Race, breast cancer subtypes, and survival in the Carolina Breast Cancer Study. J Am Med Assoc 2006, 295:2492.

11. Bernstein L, Lacey JV Jr: Receptors, associations, and risk factor differences by breast cancer subtypes: positive or negative? I Nat/ Cancer Inst 2011, 103:451-453.

12. California Cancer Reporting System Standards: In Cancer Reporting in California, System Standards: Abstracting and Coding Procedures for Hospitals. Volume 1.. 8 edition. Sacramento: California Cancer Registry, Data Standards and Quality Control Unit; 2008.

13. Perou CM, Sorlie T, Eisen MB, van de Rijn M, Jeffrey SS, Rees CA, Pollack JR, Ross DT, Johnsen H, Akslen LA, Fluge O, Pergamenschikov A, Williams C, Zhu SX, Lonning PE, Borresen-Dale AL, Brown PO, Botstein D: Molecular portraits of human breast tumours. Nature 2000, 406:747-752.

14. Sorlie T, Perou CM, Tibshirani R, Aas T, Geisler S, Johnsen H, Hastie T, Eisen MB, van de Rijn M, Jeffrey SS, Thorsen T, Quist H, Matese JC, Brown PO, Botstein D, Eystein Lonning P, Borresen-Dale AL: Gene expression patterns of breast carcinomas distinguish tumor subclasses with clinical implications. Proc Natl Acad Sci USA 2001, 98:10869-10874.

15. The 2012 Statistical Abstract: Births, Deaths, Marriages, \& Divorces; Table 83. Total Fertility Rate by Race and Hispanic Origin: 1980 to 2008. [http://www.census.gov/compendia/statab/2012/tables/12s0084.pdf].

16. Ruggles S, Sobek M, Alexander T, Fitch CA, Goeken R, Hall PK, King M, Ronnander C: Integrated Public Use Microdata Series: version 4.0. Minneapolis, MN; 2009

17. Surveillance Research Program, National Cancer Institute: SEER*Stat software [www.seer.cancer.gov/seerstat] Version 6. 5.2.

18. Dawood S, Hu R, Homes MD, Collins LC, Schnitt SJ, Connolly J, Colditz GA Tamimi RM: Defining breast cancer prognosis based on molecular phenotypes: results from a large cohort study. Breast Cancer Res Treat 2011, 126:185-192

19. Joslyn SA, Foote ML, Nasseri K, Coughlin SS, Howe HL: Racial and ethnic disparities in breast cancer rates by age: NAACCR Breast Cancer Project. Breast Cancer Res Treat 2005, 92:97-105.

20. Brinton LA, Sherman ME, Carreon JD, Anderson WF: Recent trends in breast cancer among younger women in the United States. J Natl Cancer Inst 2008, 100:1643.

21. Ihemelandu CU, Naab TJ, Mezghebe HM, Makambi KH, Siram SM, Leffall LD $J r$, DeWitty RL Jr, Frederick WA: Treatment and survival outcome for molecular breast cancer subtypes in black women. Ann Surg 2008, 247:463-469.

22. Reynolds P, Hurley S, Goldberg D, Quach T, Rull R, Von Behren J: An excess of breast cancer among young California-born Asian women. Ethn Dis 2011, 21:196-201.

23. Shavers VL, Harlan LC, Stevens JL: Racial/ethnic variation in clinical presentation, treatment, and survival among breast cancer patients under age 35. Cancer 2003, 97:134-147.

24. Anderson WF, Jatoi I, Sherman ME: Qualitative age interactions in breast cancer studies: mind the gap. J Clin Oncol 2009, 27:5308.

25. Heron M, Sutton PD, Xu J, Ventura SJ, Strobino DM, Guyer B: Annual summary of vital statistics: 2007. Pediatrics 2010, 125:4-15

26. Krieger N, Chen JT, Waterman PD: Temporal trends in the black/white breast cancer case ratio for estrogen receptor status: disparities are historically contingent, not innate. Cancer Causes Control 2011, 22:511-514.

27. Phipps Al, Chlebowski RT, Prentice R, MCTiernan A, Stefanick ML, WactawskiWende J, Kuller LH, Adams-Campbell LL, Lane D, Vitolins M, Kabat GC, Rohan TE, Li Cl: Body size, physical activity, and risk of triple-negative and estrogen receptor-positive breast cancer. Cancer Epidemiol Biomarkers Prev 2011, 20:454-463.

28. Phipps Al, Chlebowski RT, Prentice R, McTiernan A, Wactawski-Wende J, Kuller LH, Adams-Campbell LL, Lane D, Stefanick ML, Vitolins M, Kabat GC, Rohan $T E, L i$ Cl: Reproductive history and oral contraceptive use in relation to risk of triple-negative breast cancer. J Natl Cancer Inst 2011, 103:470-477.

29. Phipps Al, Malone KE, Porter PL, Daling JR, Li Cl: Reproductive and hormonal risk factors for postmenopausal luminal, HER-2overexpressing, and triple-negative breast cancer. Cancer 2008, 113:1521-1526. 
30. Kurian AW: BRCA1 and BRCA2 mutations across race and ethnicity: distribution and clinical implications. Curr Opin Obstet Gynecol 2010, 22:72-78.

31. Yang XR, Chang-Claude J, Goode EL, Couch FJ, Nevanlinna H, Milne RL, Gaudet M, Schmidt MK, Broeks A, Cox A, Fasching PA, Hein R, Spurdle AB, Blows F, Driver K, Flesch-Janys D, Heinz J, Sinn P, Vrieling A, Heikkinen T, Aittomaki k, Heikkila P, Blomquist Cj, Lissowska J, Peplonska B, Chanock S, Figueroa J, Brinton L, Hall P, Czene K, et al: Associations of breast cancer risk factors with tumor subtypes: a pooled analysis from the Breast Cancer Association Consortium Studies. J Natl Cancer Inst 2011, 103:250-263.

32. Travis LB, Hill D, Dores GM, Gospodarowicz M, Van Leeuwen FE, Holowaty E, Glimelius B, Andersson M, Pukkala E, Lynch CF: Cumulative absolute breast cancer risk for young women treated for Hodgkin lymphoma. J Natl Cancer Inst 2005, 97:1428.

33. Althuis MD, Brogan DD, Coates RJ, Daling JR, Gammon MD, Malone KE, Schoenberg JB, Brinton LA: Breast cancers among very young premenopausal women (United States). Cancer Causes Control 2003, 14:151-160.

34. Michels KB, Terry KL, Willett WC: Longitudinal study on the role of body size in premenopausal breast cancer. Arch Intern Med 2006, 166:2395-2402

35. Ahn MK, Juon HS, Gittelsohn J: Association of race/ethnicity, socioeconomic status, acculturation, and environmental factors with risk of overweight among adolescents in California, 2003. Prev Chronic Dis 2008, 5:A75

36. Babey $\mathrm{SH}$, Hastert TA, Wolstein J, Diamant AL: Income disparities in obesity trends among California adolescents. Am J Public Health 2010, 100:2149-2155

37. Gaudet MM, Press MF, Haile RW, Lynch CF, Glaser SL, Schildkraut J, Gammon MD, Douglas Thompson W, Bernstein JL: Risk factors by molecular subtypes of breast cancer across a population-based study of women 56 years or younger. Breast Cancer Res Treat 2011, 130:587-597.

38. Malone KE, Daling JR, Neal C, Suter NM, O'Brien C, Cushing-Haugen K, Jonasdottir TJ, Thompson JD, Ostrander EA: Frequency of BRCA1/BRCA2 mutations in a population-based sample of young breast carcinoma cases. Cancer 2000, 88:1393-1402

39. Gonzalez KD, Noltner KA, Buzin CH, Gu D, Wen-Fong CY, Nguyen VQ, Han JH, Lowstuter K, Longmate J, Sommer SS, Weitzel JN: Beyond Li Fraumeni syndrome: clinical characteristics of families with p53 germline mutations. J Clin Oncol 2009, 27:1250-1256.

40. Turner NC, Reis-Filho JS: Basal-like breast cancer and the BRCA1 phenotype. Oncogene 2006, 25:5846-5853.

41. Haffty B, Choi D, Goyal S, Silber A, Ranieri K, Matloff E, Lee M, Nissenblatt M, Toppmeyer D, Moran M: Breast cancer in young women (YBC): prevalence of BRCA1/2 mutations and risk of secondary malignancies across diverse racial groups. Ann Oncol 2009, 20:1653.

42. Melhem-Bertrandt A, Bojadzieva J, Ready KJ, Obeid E, Liu DD, GutierrezBarrera AM, Litton JK, Olopade OI, Hortobagyi GN, Strong LC, Arun BK: Early onset HER2-positive breast cancer is associated with germline TP53 mutations. Cancer 2012, 118:908-913.

43. Fredholm H, Eaker S, Frisell J, Holmberg L, Fredriksson I, Lindman H: Breast cancer in young women: poor survival despite intensive treatment. PLOS One 2009, 4:e7695

44. Agnese DM, Yusuf F, Wilson JL, Shapiro CL, Lehman A, Burak WE Jr: Trends in breast cancer presentation and care according to age in a single institution. Am J Surg 2004, 188:437-439.

45. Hede K: Breast cancer testing scandal shines spotlight on black box of clinical laboratory testing. J Natl Cancer Inst 2008, 100:836-837, 844.

46. Ma H, Luo J, Press MF, Wang Y, Bernstein L, Ursin G: Is there a difference in the association between percent mammographic density and subtypes of breast cancer? Luminal A and triple-negative breast cancer. Cancer Epidemiol Biomarkers Prev 2009, 18:479-485.

47. Press MF, Sauter G, Bernstein L, Villalobos IE, Mirlacher M, Zhou JY, Wardeh R, Li YT, Guzman R, Ma Y, Sullivan-Halley J, Santiago A, Park JM, Riva A, Slamon DJ: Diagnostic evaluation of HER-2 as a molecular target: an assessment of accuracy and reproducibility of laboratory testing in large, prospective, randomized clinical trials. Clin Cancer Res 2005, 11:6598-6607.

48. Hammond ME, Hayes DF, Dowsett M, Allred DC, Hagerty KL, Badve S, Fitzgibbons PL, Francis G, Goldstein NS, Hayes M, Hicks DG, Lester S, Love R,
Mangu PB, McShane L, Osborne CK, Paik S, Perlmutter J, Rhodes A, Sasano H, Schwartz JN, Sweep FC, Taube S, Torlakovic EE, Valenstein P Viale G, Visscher D, Wheeler T, Williams RB, et al: American Society of Clinical Oncology/College Of American Pathologists guideline recommendations for immunohistochemical testing of estrogen and progesterone receptors in breast cancer. J Clin Oncol 2010, 28:2784-2795.

49. Wolff AC, Hammond ME, Schwartz JN, Hagerty KL, Allred DC, Cote RJ, Dowsett M, Fitzgibbons PL, Hanna WM, Langer A, et al: American Society of Clinical Oncology/College of American Pathologists guideline recommendations for human epidermal growth factor receptor 2 testing in breast cancer. Arch Pathol Lab Med 2007, 131:18-43.

50. Carlson RW, Allred DC, Anderson BO, Burstein HJ, Carter WB, Edge SB, Erban JK, Farrar WB, Goldstein LJ, Gradishar WJ, Hayes DF, Hudis CA, Jahanzeb M, Kiel K, Ljung BM, Marcom PK, Mayer IA, McCormick B, Nabell LM, Pierce LJ, Reed EC, Smith ML, Somlo G, Theriault RI, Topham NS, Ward JH, Winer EP, Wolff AC: Breast cancer: clinical practice guidelines in oncology. J Natl Comp Cancer Netw 2009, 7:122-192.

51. Clegg LX, Reichman ME, Hankey BF, Miller BA, Lin YD, Johnson NJ, Schwartz SM, Bernstein L, Chen WW, Goodman MT, Gomez SL, Graff JJ, Lynch CF, Lin CC, Edwards BK: Quality of race, Hispanic ethnicity, and immigrant status in population-based cancer registry data: implications for health disparity studies. Cancer Causes Control 2007, 18:177-187.

52. Gomez SL, Glaser SL: Misclassification of race/ethnicity in a populationbased cancer registry (United States). Cancer Causes Control 2006, 17:771-781.

\section{doi:10.1186/bcr3156}

Cite this article as: Keegan et al:: Occurrence of breast cancer subtypes in adolescent and young adult women. Breast Cancer Research 201214 : R55.

\section{Submit your next manuscript to BioMed Central and take full advantage of:}

- Convenient online submission

- Thorough peer review

- No space constraints or color figure charges

- Immediate publication on acceptance

- Inclusion in PubMed, CAS, Scopus and Google Scholar

- Research which is freely available for redistribution

Submit your manuscript at www.biomedcentral.com/submit
C Biomed Central 